\title{
A Crisis of Gerontocracy and the Coventry Play
}

Theresa Coletti was the first to draw attention to Coventry's gerontocratic civic structure as a context integral to identifying central themes in the city's remaining pageants. ${ }^{1}$ Emphasizing the importance of reading medieval dramatic texts within their detailed historical contexts, Coletti argues that 'The central conflict in each [pageant] is between youth and age'. ${ }^{2}$ Acknowledging the biblical source of this conflict, she nonetheless suggests that the pageants 'also reflect the social order in the fabric of everyday life in late medieval Coventry'. ${ }^{3}$ More recently, Brandon Alakas has explored the gerontocratic theme of the extant pageants in detail. ${ }^{4}$ Focusing on the Weavers' pageant in particular, Alakas distinguishes between depictions of age in familial, artisanal, and civic contexts within the pageant. He also engages in a nuanced discussion of the pageant's language, demonstrating that the text plays 'on the semantic ranges of certain words such as misteri and maister in order to collapse further events portrayed on stage with the everyday lives of the audience'. 5 Like Coletti, Alakas argues for the presence of local contexts and concerns within the framework of the biblical narrative.

Both Coletti and Alakas demonstrate that the extant Coventry pageants reflect the gerontocratic society which fostered them. At the same time, however, both scholars also read the pageants as foreclosing debate: Coletti's brief analysis sees the pageants as supporting the hegemonic order, while Alakas's more detailed consideration concludes that the Weaver's pageant provides alternatives to that order in the face of economic and political crisis. ${ }^{6}$ In doing so, both reflect a general tendency in recent medieval drama scholarship to read cycle drama as the result of conflictual social relations, whereby cycles are seen to represent either the authoritarian perspective of the ruling elite or a struggle between the social vision of that elite and the agendas of the sponsoring craft associations. This approach to interpretation developed in response to the more optimistic readings of scholars such as Mervyn James and Charles Phythian-Adams, who saw the ceremonial or ritual function of 
cycle drama as fostering social cohesion. ${ }^{7}$ While I do not advocate a wholesale return to this earlier theory of cycle drama's social function, I do feel that a conception of the civic context as a functioning whole can shift our understanding of what these texts meant to their audiences and, in particular, how they engaged their audiences in the consideration of social issues of importance to the majority of civic residents. With respect to the extant Coventry pageants, a closer examination of texts and contexts reveals that these pageants raise more questions about the gerontocratic crisis than answers. The pageants participate in a contemporary conversation about the future of Coventry's civic structure rather than didactically imposing a solution to the crisis, and they do so by highlighting a central demographic problem facing the city. In the material that follows I will review Coventry's gerontocratic structure and, in particular, Alakas's reading of the Weaver's pageant, before re-examining the conclusions of both extant pageants. While Alakas provides a useful analysis of gerontocracy and shifting linguistic registers in the Weaver's pageant, a more exact consideration of the interplay between text and context demonstrates an open-ended depiction of Coventry's gerontocracy in crisis.

Charles Phythian-Adams discusses Coventry's gerontocratic system in 'Ceremony and the Citizen' and The Desolation of a City: Coventry and the Urban Crisis of the Late Middle Ages. ${ }^{8}$ What he calls the 'successful citizen' would progress through the civic hierarchy, starting with minor craft offices such as summoner or beadle and culminating in the upper echelons of the mayoralty and council. ${ }^{9}$ The city's two religious guilds, the Corpus Christi Guild and the Trinity Guild, formed a key part of this system. Citizens who aspired to higher civic positions would join the Corpus Christi Guild fairly early in their careers and soon take on minor civic functions, such as chamberlain or warden, which in turn lead to membership in the common council. ${ }^{10}$ Ten to fifteen years later, these men would transfer to the Trinity Guild and become eligible for the position of sheriff and membership in the Leet. Still later, a citizen might become, in close succession, master of the Corpus Christi Guild, mayor, and finally master of the Trinity Guild, thereby securing his position as an alderman for the rest of his life. Given that these last three positions were usually taken up by men in their fifties and sixties, their stint on the council might not be long, but the system ensured that the most experienced men were at the top of the hierarchy. Progress through the system was effectively limited to the wealthier trades, generally the mercantile ones, 
due to the costs incurred by these offices, but the system was also fairly flexible and allowed new participants to rise regularly through the ranks.

In a time of economic crisis, however, such as that which peaked between 1518 and 1525, the gerontocratic system broke down. Phythian-Adams describes how the declining cloth trade, which affected England as a whole in the mid-fifteenth century, and Coventry's central political and geographical position during the War of the Roses generally reduced trade and siphoned funds out of the city, which in turn led to the depletion - or desertion - of the city's wealthier employers. The first half of the sixteenth century saw these problems compounded by famine and pestilence, which further reduced the city's population. ${ }^{11}$ Under these circumstances, the established gerontocracy began to falter. This occurred both because of a lack of eligible participants, a factor Phythian-Adams discusses in detail, ${ }^{12}$ and because the system tended to entrench the more conservative older members of society in the highest positions of authority. Whether out of self-interest or a desire to protect civic customs, these conservative elders were resistant to change. In 1539, for example, Mayor Coton had to appeal to Cromwell's external authority for assistance in changing expensive civic traditions that were proving detrimental in a time of economic crisis. Citing mayoral inauguration feasts, the Corpus Christi pageants, and craft celebrations at Midsummer's and St Peter's Eve, Coton notes twice that the commoners have asked for a reduction in these financial burdens. He claims, however, to be unable to enact such changes without Cromwell's mandate because the aldermen, all ex-mayors themselves, 'being past all suche offices $\&$ charges do little regarde theme that be to com / ner do not esteem the vndoyng of half a dosen honest Comeners to be so ill a deid / as is the omyttyng \& lesyng of on accustomed drynkyng. ${ }^{13}$ Coton paints a picture of the elderly authorities ignoring the economic crisis and insisting that the younger members of the civic structure beggar themselves in customary celebrations, both those associated with craft activities and those attendant on participation in the civic structure. During times of economic crisis, the strength and stability of gerontocracy could become a weakness when the city needed more responsive governance.

Both of the extant Coventry pageants were revised in the wake of the high point of crisis. The first suggestion of a cycle play in Coventry dates to 1392 , while the cycle was last performed in $1579 .{ }^{14}$ The only surviving texts, however, are those revised by Robert Croo in 1535: the Shearmen and Taylors' pageant, spanning the Nativity to the Slaughter of the Innocents, and the Weavers' pageant, depicting the Presentation at the Temple and Christ's Dis- 
putation with the Doctors. ${ }^{15}$ Colophons at the end of the two pageants state that the Shearmen and Taylors' pageant was 'nevly correcte' on March 14 and the Weavers' pageant was 'nevly translate' on March 2 in 1534, which Pamela King and Clifford Davidson identify as old style dating for $1535 .{ }^{16}$ Written ten years after the worst of the crisis and in a period of continued economic restriction, these revisions are ideally situated to reflect the city's social concerns in response to the economic crisis. As both Coletti and Alakas argue, gerontocratic principles are explored and even celebrated in both pageants, signaling a continued nostalgia for this political and social system. Alakas's discussion of the Weavers' pageant in particular demonstrates the degree to which the revised texts idealize the gerontocratic system.

The Weavers' pageant begins with a discussion between two prophets, followed by an extended Presentation sequence which includes both a long lamentation by Simeon concerning his advanced age and several comic episodes surrounding Joseph's old age and his marriage to a young wife. ${ }^{17}$ The final section of the pageant involves the holy family's journey to Jerusalem during a festival, their loss of Jesus on the way home, and their eventual discovery of him in disputation with the Doctors, whom he has impressed with his knowledge of the Ten Commandments. Alakas reads 'Joseph's diminished status' and 'loss of authority within the household' as a negative representation of age, but he demonstrates how other depictions of age are more positive when traditional hierarchies are upheld. ${ }^{18}$ For example, he sees the discussion between the two prophets as a triumphant depiction of age-related authority in the master-apprentice relationship. He comments that the prophets' biblical gloss is expressed 'in language capable of spanning the two worlds of biblical narrative and artisanal culture'. ${ }^{19}$ In particular, he notes that the second prophet's 'desire to know where and how this "worthe mystere" is to be "vsid" seems slightly out of place in a theological linguistic register', but that 'his desire to understand the function and application of this knowledge makes perfect sense within an artisanal context'. ${ }^{20}$ Although Alakas does not note it, a similar relationship is developed between Simeon and his clerks. When an Angel warns Simeon that Christ will arrive later in the day, he commands his clerks to 'wayte and serve with all delegence' (338), and one clerk replies,

To serve a prynce of soche magneffecens,

Sir, I wasse neuer wont therto.

Sythe ye perin hathe more intelligence, 
Instructe me, sir, how pat I schuld do

Lest that I do offende.

The context is theological, and the relationship is one of a teacher and student, but the emphasis on service and appropriate physical action continues the double register of the previous scene, again evoking the master-apprentice relationship. Simeon is impressed with his clerk's desire to learn, saying, 'Sith that ye for knoleyge dothe make sute, / Your wyttis the bettur do I reypute' (349-50), and he proceeds to instruct the clerks in their duties. Later, when Christ approaches, he urges the clerks into position, and one responds, 'Loo, mastur, bothe man and place, / Be all redde at your byddeng' (618-9). As with the second prophet, the clerks act as the ideal students, but also as ideal apprentices, deferring to the wisdom and experience of their master and portraying obedience and a desire to learn. In the scenes of the prophets and of Simeon with his clerks, the ideal of gerontocratic authority would appear to be intact, and the double register encourages a mapping of this authority onto craft relationships as well.

Alakas contrasts this appearance of stable craft gerontocracy with that of the civic system as represented in the interactions between Christ and the Doctors. His evidence for reading this scene in a specifically civic context relies on language which he describes throughout his article as artisanal, such as 'mystere' and 'secrettis'. He notes that 'mistere ... can refer either to a theological mystery or to the skill of a guild (the meaning in the Leet Book)' while 'secret ... can refer either to a divine mystery hidden from human understanding or the science of a craft known only to the initiated'. ${ }^{21}$ When this language occurs in the Christ and the Doctors scene, he argues that it 'helps to facilitate the identification of the Doctors with the aldermanic elite that rule Coventry. ${ }^{22}$ While this language can apply to a civic structure which is based on participation in religious guilds, it is less effective in suggesting the register of civic authority when it has already been established as evoking religious and artisanal contexts in earlier scenes. Moreover, eliding civic and artisanal language undermines this scene's multiple referents. Rather than shifting from a craft to a civic context, the scene maintains the semantic range of religious and artisanal language while adding a third register of civic authority. Both the linguistic and the phenomenological experience of the Doctors' opening lines situates them as simultaneously religious and civic authority figures. In addition to evoking a linguistic double register, the scene also employs tactics of character ambiguity and delayed exposition to encourage an experience 
of the performance which invokes both biblical and civic contexts. Beyond doubt, a contemporary audience would know the religious story unfolding and be able to identify the characters on stage, but delayed exposition allows the double register to develop, suggesting a locally contextualized reading of the scene in conjunction with its more traditional biblical meaning.

The performative ambiguity begins with the physical appearance of the characters on stage. As King and Davidson note, the play's gestic language follows the tradition of contemporary English depictions in stained glass, manuscript illumination, and even a roof boss, by having the Doctors wear furs and carry books. The surviving static images depict the Doctors wearing 'fur-lined hoods and academic caps and gowns' and 'their distinctive academic caps', and it is likely that the stage production followed suit. ${ }^{23}$ In other words, the Doctors were probably costumed as scholars, not Jews. The furs and books are symbols of wealth and authority, but there is no overt suggestion that this authority is specifically religious or that the Doctors were visually marked as Jewish. Instead, this visual ambiguity only allows that the Doctors are figures of intellectual authority, scholars or, as the double register of the first Doctor's opening speech implies, civic elders.

Without identifying himself, the first Doctor opens the scene by seizing the audience's attention:

Now, lordyngis, lystun to me a whyle,

Wyche hathe the lawis vndur honde,

And that no man fawll in soche perell

Agenst any artyccull for to stand,

For the comen statute of this lande

Woll that all such personys schulde be tane,

And in the face of peple ooponnly slayne. (850-6)

The Doctor identifies himself as being responsible for laws that carry the threat of public execution when contravened. The audience is given no indication as to which laws the Doctor is discussing, but the threat of a death penalty implies a serious and potentially secular matter, since Christian religious authorities were not permitted to dispense corporal punishment. As King and Davidson's footnotes suggest, these lines refer to Jewish law, but this reference is not made explicit, leaving room for the development of a double register of both religious and secular authority. ${ }^{24}$ The language also echoes expressions used in Leet orders in its concern for the administration of justice 
and its emphasis on common statutes. While 'statute' can mean 'a religious ordinance made by Jewish authorities' it also refers to secular law, including 'an ordinance of a town or city', a resonance strengthened by the addition of 'comon', suggesting secular common law. ${ }^{25}$ Similarly, the word 'artyccull' has both religious and secular connotations. ${ }^{26}$ Only when the second Doctor speaks, identifying the characters as Jewish clergy disputing the Commandments, is the necessary exposition for the scene supplied, and by this point the double register is firmly established. The initial verbal and visual ambiguity conflates the religious story with the performance's civic context, encouraging a continued awareness of the double register and an interpretation of the Doctors as civic elders. The second Doctor states, for example, that they employ the 'polatike syence of clarge clere' (863) in their debates, invoking the double meaning of 'polatike' as 'spiritual or secular governance'. ${ }^{27}$ While the context gives priority to a religious interpretation, the established double register maintains the secular connotation as well. Finally, the third Doctor formally commands the audience to

now draw nere,

And in this place gewe your attendence.

How ye schuld lyve here ma you lere,

Acordyng vnto your aleygence;

For yt ys well knowe vnto this presence

Thatt doctoris we ar and of hy degree,

And haue the lawis in custode.

$(864-70)$

Here again, 'aleygence' can refer to religious and secular contexts. ${ }^{28}$ While there is no record of how Leet sessions were called to order, this speech implies a formal legal gathering as much as a religious disputation, and could perhaps have been a direct reference to Leet practices for local members of the audience. ${ }^{29}$ Overall, the number of words that evoke a double register in conjunction with the allusion to secular punishment and legal proceedings establishes a parallel reading of the Doctors as both religious and civic leaders.

This impression that this scene evokes a civic context gains strength through comparison of the Coventry pageant to related versions of the episode from other cities. There are four extant analogues of the Christ and the Doctors episode, from York, Chester, Towneley, and Coventry, although York is believed to be the earliest. While all versions stress the Doctors' authority over the laws, only Coventry uses words like 'artyccull', 'comen statute', 'pola- 
tike', or 'aleygence', and none of the other versions delay recognition of the Doctors as religious (as opposed to secular) figures the way Coventry's version does. The contrast suggests that the reviser intentionally altered his source to develop a subtextual reading of the Doctors as civic authority figures. At the same time, it is also possible to continue reading the scene as a commentary on craft practices. As Alakas notes, the artisanal language which characterizes the other two scenes in the pageant continues into this scene: references to 'secrettis' and 'mystere' invoke a craft discourse as well as a religious one, while Christ's recitation of the fourth commandment 'demonstrates a greater sensitivity towards the material realities of living in a highly competitive commercial market'. ${ }^{30}$ This language in turn constructs the Doctors as craft masters. In other words, while this section of the pageant is most certainly about the biblical story of Christ's disputation with the Doctors, it is also about both civic and craft authority.

With respect to civic authority, Alakas concludes that 'this pageant appears to take aim at and dismantle the discourse which the city's aldermanic clique used to position itself at the head of the civic corporation'. ${ }^{31}$ He ultimately argues, however, that the Weavers 'present a vision wherein a gerontocratic ideal gives way to a more equitable and less stratified set of social arrangements as the Doctors finally admit Christ among their ranks'. ${ }^{32}$ It is at this point that I disagree with Alakas's conclusions. While the Christ and the Doctors episode does indeed reflect anxieties about threats to and the failure of the gerontocratic system, these anxieties are not resolved by the Doctors' acceptance of Christ, because Christ does not stay with them. His departure at the end of the pageant signals a disruption of traditional craft and civic practices, and the pageant ends on a troubled note wherein both the Doctors and Christ's parents express social anxieties in keeping with Coventry's economic and demographic crisis.

As Daniel Kline notes in his comparison of the four analogous Christ and the Doctors pageants, Coventry's Christ is 'the most recognizably childlike figure of the four plays'. ${ }^{33}$ King and Davidson concur, drawing attention to lines added in the Coventry version which 'have two adults discussing Jesus over his head, as it were, ... thus adding to the play's characterization of him as plausibly childlike. ${ }^{34}$ Alakas sees this emphasis on Christ's youth as highlighting the age differences, ${ }^{35}$ drawing attention to the gerontocratic context, but speeches about and to Christ also characterize his youth as the quality which makes him especially precious. From the moment that the holy family leaves Simeon's temple, Mary and Joseph repeatedly marvel at their good 
fortune in having a 'soo goodly a childe' (721) who 'waxith feyre and large' (729). Mary dotes on Jesus, calling him 'he that I love most dere, / My joie, my myrthe, and all my pley' (737-8), and demonstrates anxiety about losing her child in the crowd well before Christ slips away. When he does disappear, both Mary and Joseph exhibit genuine distress, and Mary's tone of despair and anguish intensifies during Joseph's unsuccessful attempts to console her. Only the York analogue includes a similar development of parental distress. ${ }^{36}$ The section dealing with the discovery of Christ's absence is longer in the York text (thirty-four lines as compared to twenty-eight lines in Coventry), but the rapidity of dialogue in the Coventry version heightens the anxiety of the shorter scene. There are eight shifts between characters in the York version, with an average of four lines per exchange. These exchanges in the York text include both an eight- and a six-line passage, while there is only one instance of a two-line passage. In contrast, there are nine shifts between characters in the Coventry version, with an average of three lines per exchange. Five of these Coventry exchanges are four-line passages, and four are two-line passages. The six- and eight-line sections of the York version allow an actor to gain momentum in developing an emotional register, but they also encourage more stylized representations, whereas the rapid dialogue of the Coventry version suggests a more naturalistic portrayal of distress. In contrast to this distress, Mary's relief when they find Jesus is palpable, an effect not achieved in the other Christ and the Doctors pageants, despite the similarity of language in the reunion passages, because the other versions do not establish an emotional involvement at the start of the episode to the same degree. The result is that the character of Jesus becomes purposefully invested with the qualities of childhood (as opposed to divinity or even burgeoning maturity); he is not just an abstract representation of childhood, but the specific child of loving and human parents. The figural distance of the holy family is effectively stripped away, and audience members are invited to empathize with these religious figures based on a common experience of parenthood.

The scene which follows the reunion of the holy family is unique to Coventry and speaks volumes in the context of demographic crisis. Christ's age has specific implications with respect to local customs concerning apprenticeship, implications that the text draws attention to, but the biblical narrative necessarily requires a frustration of these local practices. Having established a double vision of local and biblical contexts throughout the pageant, the scene raises anxieties about social realities when these two narratives come into conflict. At the beginning of the Christ and the Doctors section, Mary 
specifically identifies Jesus as being 'xij yere of age' (727), the age which Phythian-Adams equates with the beginning of adolescence in Coventry. He identifies twelve years as the age when boys were included in the tithing system, positing that 'only in wealthier households did boys remain at home after that age'. ${ }^{37}$ As the son of a carpenter, Jesus would be of an age to go into service or take up an apprenticeship. ${ }^{38}$ It echoes local customs, then, that when Jesus bids farewell to the Doctors, they express an interest in having him stay:

DOCTOR II. Now that Lorde of lordis be thy spede Where eyuer thow goo in any cruoft, But yff thow wolt tarre thow schalt not nede Any more to put thy fryndis to cost.

DOCTOR III. How seyst thow, fathur, for thy good wyll?

Wolt thow grant pi help thyre tyll Awey thatt, sir, he do not goo?

On the level of the religious narrative, the Doctors are inviting Christ to join them as a student. The double register which also constructs these Doctors as craft masters, however, along with the second Doctor's intimation that Jesus need no longer be a financial burden on his parents, implies that Jesus is invited to become an apprentice. A key word in this exchange is 'fryndis': 'frend' can mean both 'a benefactor [or] a patron' and 'a kinsman [or] a blood relative'. ${ }^{39}$ The second Doctor's statement that Jesus 'not nede/ Any more to put [his] fryndis to cost' (1081-2) alludes to the sponsorship that Christ might seek as a student entering school, ${ }^{40}$ but the statement oddly reverses common practice, suggesting that he will be tutored at the Doctors' expense. In an artisanal context, however, the statement fits with local customs. As Phythian-Adams notes, several craft ordinances specified that masters were expected to provide their apprentices with room and board, ${ }^{41}$ a practice that explains why Christ, as apprentice, would not need financial support from his parents. At the same time, the reference to the 'help' which Joseph can grant may euphemistically refer to the financial aspects of apprenticeship negotiation, since apprentices (or their sponsors) had to pay, at the least, a civic indenturing fee of $12-24 \mathrm{~d} .{ }^{42}$ Moreover, the third Doctor's appeal to Joseph as the nominal head of the household acknowledges the father-figure as the owner of Christ's potential labour, initiating an apprenticeship negotiation. ${ }^{43}$ 
The requirements of the biblical narrative must at this point diverge from the expectations of local custom: for the purposes of the biblical story, Christ cannot stay with the Doctors. The resultant disruption of the underlying artisanal narrative is signaled by the vehemence with which Joseph and Mary resist the suggestion that Christ remain with the Doctors. Joseph will not part with his son 'for frynde nor foo' (1088), while Mary begs the Doctors 'Do ye not wyll my chylde fro me', adding, 'For with my wyll yt schall nott be / Whyle that owre lyvis last' (1093-6). This reluctance to part with a child at the age of apprenticeship seems unreasonable in the context of local custom, and the first Doctor's response betrays an impatient frustration:

Then yt ys noo bote for to intreyte,

Thy chylde I see I canot gete;

I tro yt be but wast to speyke,

Thatt tyme I thynke ys past.

The conflict of expectations, both in the text and on the part of the audience, creates an emotional rupture which echoes and reinforces an unarticulated anxiety on the part of all the scene's adult participants. As the scene continues, there are intimations that this anxiety is rooted in local concerns over high mortality rates and a consequently destabilized civic structure.

Jesus again bids the Doctors farewell, and the second Doctor speaks for them all when he tells Christ to visit them if he passes that way again. His speech ends ominously, however, when he adds, 'Yff thow to age lyve may, I Thy fryndis ma be full glade' (1107-8). This comment may simply be foreshadowing Christ's death on the cross, but the intimation of child mortality puts the heightened conflict of local and biblical contexts into a different perspective by alluding to a real demographic crisis. In Chapter 21 of Desolation of a City, Phythian-Adams analyzes the available data on the number of children in Coventry in 1523, concluding that there was an 'existing paucity of children' and that 'what remained of Coventry's population in 1523 was already beginning to breed itself out of existence'. ${ }^{44}$ The population which had already been decimated by disease, famine, and emigration was not producing enough children to replace itself, and Phythian-Adams suggests that the situation did not improve in the following decades. ${ }^{45}$ The textile industries were particularly affected by these low replacement rates, both in terms of children and of servants, the latter of which could include apprentices. Among the textile crafts, 55.7\% of households contained chil- 
dren, as opposed to $75 \%$ of merchant households, and $60.8 \%$ of households contained servants, as opposed to $90 \%$ of merchant households. 46 While the wealthier merchants were generally able to hold their ground in the face of the demographic crisis, textile craftsmen were not producing enough children or training enough apprentices to maintain their crafts in the future. Weavers in particular had a low replacement ratio for servants, suggesting their imminent disappearance from the city's artisanal landscape. Phythian-Adams states that 'a ratio of between 0.8 and $0.9 \ldots$ roughly indicates the danger level. Any score below this almost certainly reflects the decline of the occupation or category in question'. He adds that 'The perilously low replacement ratio of 0.4 recorded for the Weavers, for instance, undoubtedly betrays grim realities in this sector of the economy', and he confirms a drop in the number of master weavers in the 1530s. ${ }^{47}$ The Weavers who commissioned Croo's 1535 revision of their pageant would have been aware of the impact demographic trends were having on their trade and were likely concerned with reversing their trade's decline.

In this context, Mary and Joseph's protectiveness of their child and the Doctors' disappointment over their failure to keep him with them reflects a general anxiety over the paucity of children and its implications with respect to the future populations of Coventry as a whole and Weavers in particular. This anxiety haunts the remainder of the pageant and underpins the failure of gerontocratic authority. For their part, Mary and Joseph seem overeager to return home. While Joseph announces the equivalent of 'At Nazarethe now I wolde we weyre' (1118) in all three of the York, Towneley, and Coventry analogues, only in Coventry does Mary concur: 'Whereoff am I right fayne' (1121). The Coventry version adds further lines which increase the sense of urgency:

JOSOFFE. In this place whyle we ar here

Loke thatt we haue all owre gere

Thatt we cum nott agayne.

MARE. Josoffe, husebonde, we myse nothing,

But at youre wyll let vs be gooyng

Asse fast ease eyuer we can.

While these lines indicate practical actions, they also express a desire to leave as quickly as possible and to ensure that there is no reason to return, as if the holy family does not quite trust that the Doctors will let them leave with their 
son. In turn, the Doctors' closing speeches, while ostensibly celebrating their meeting with God's elect child, also suggest discomfiture with the reversal of their authority. This reversal occurs both on the biblical level of the narrative, in that Christ represents the new law that the Doctors must now learn, but also on the civic and artisanal levels, in that Christ's departure denies the Doctors' hierarchical authority. The third Doctor's speech reveals an anxiety specifically rooted in the failure of authority:

Ys not thys a wondurs case,

That pis yonge chylde soche knolege hase?

Now surely he hath asposschall grace,

Soo hy dowtis desernyng,

Thatt we wyche nobull doctors be,

And gradudis gret of old antequete,

And now on this place with yonge infance,

Ageyne ar sett to larning.

The educational hierarchy, whether religious or artisanal, is inverted when the child publicly outstrips the knowledge of his elders and sets them "Ageyne ... to larning'. While all three Doctors marvel at Christ's abilities and conjecture his divine inspiration, it is the third of these admiring speeches that draws attention to the simultaneous reversal of the Doctors' authority. They must again become students because the knowledge they had mastered no longer applies. In response to this speech, the first Doctor recommends that all three leave in order to avoid 'more perell' (1165). On the surface, this is a puzzling statement, since the Doctors are in no obvious danger, but the real threat is to their authority. By challenging the Doctors' knowledge in a public forum and then leaving despite their clear desire to have him stay, Christ undermines the authority that the Doctors had claimed over the audience at the start of the scene. The first Doctor attempts to regain that authority as he formally dismisses the audience:

All owre matters reyjurned be,

Tyll that a dey of argument

Ma be apwyntyd indyfferentle,

Where all you the comenalte,

You ma departe on this condyssion,

Thatt ye atende at the next monyssion. $\quad$ (1174-80) 
He gives the audience permission to leave on the condition that they will reassemble when commanded to do so, or in other words, so long as they recognize his authority. Following so close on Christ's challenge and the Doctors' recognition of the need for further study, this insistence on authority serves only to draw attention to its waning power.

As with the scene's opening speeches, the Doctor's dismissal evokes the double register, with the word 'comenalte' alluding to civic and artisanal contexts. ${ }^{48}$ Within these contexts, the dangers that the Doctors face may also allude to the real perils of plague, famine, and economic dissolution which led wealthier citizens to desert the city, further undermining both the local economy and the gerontocratic structure. As with Mayor Coton's complaint to Cromwell, the scene's conclusion implies a higher civic echelon privileging its own interests over those of the honest commoners: the Doctors may leave to escape danger, but the commoners must remain close by and respond when called. The resonance of a secular context in this conclusion again situates the episode in familiar civic territory, transferring the anxieties of the characters and the consequences of their decisions onto the social realities faced by the audience.

Framed by these civic references and allusions to craft practices, the religious narrative of the Christ and the Doctors episode takes on additional meaning in reference to both craft and civic gerontocratic structures. Jesus is both a potential apprentice and the 'honest commoner' who might one day be eligible to take up civic office, so his removal from the system becomes a double threat. The ideals of gerontocracy established in the earlier two episodes of the pageant, by the prophets and Simeon, are disrupted by the absence of new members at the bottom of the hierarchy. While vaguely threatening and potentially preparing to desert the city, the older members of that hierarchy are depicted as eager to pass on their knowledge and power, but they are helpless and themselves reduced to students when there are no younger participants in the hierarchy. The pageant as a whole leaves the audience uncertain and mourning the loss of the gerontocratic system; they are forced to recognize the failure of their ability to achieve the ideal.

Intriguingly, this anxiety over the lack of children in Coventry and the pattern of depicting the gerontocratic ideal followed by its disruption occurs in the other pageant revised in 1535. The Shearmen and Taylors' pageant begins with the Annunciation and Nativity, including episodes with the Shepherds and the Three Kings, all of which celebrate the birth of Jesus and the salva- 
tion he brings. Positive representations of gerontocratic authority include the three kings who recognize and worship the infant Christ as well as a number of prophets who discuss the Incarnation and 'act as repositories of ancient wisdom'. ${ }^{49}$ The pageant ends, however, with a Slaughter of the Innocents episode, and this version of the story is markedly different from that of other English cycle plays. In the York and Towneley plays, the knights commanded to kill all the male children in Bethlehem have no qualms about doing so. In the Chester version, the knights only resist initially because they think killing children is beneath them. Once they are assured that 'the labor they are being asked to perform is suitable for their social standing, ${ }^{50}$ they participate eagerly. In Coventry, however, the knights resist for ethical and political reasons. When Herod asks them, 'ys not this the best red / Thatt all yong chyldur fro this schuld be dede, / Wyth sworde to be slayne?' (731-3), the knights respond negatively:

MYLES I. My lorde, Kyng Erode be name,

Thy wordis agenst my wyll schal be.

To see soo many yong childer dy ys schame;

Therefore consell perto gettis pou non of me.

MYLES II. Well seyd, fello, my trawth I plight.

Sir kyng, perseyve right well you may,

Soo grett a morder to see of yong frute

Wyll make a rysyng in pi noone cuntrey.

They warn Herod that the deed is not only shameful but also dangerous, since it will incite rebellion, but Herod refuses to listen, threatening the knights until they promise to do his bidding. Nonetheless, when they engage in the slaughter, they continue to express their reluctance by identifying Herod as the source of their actions. They 'mvst fullfyll Erodis commandement, / Elis be [they] asse trayturs and cast all in care' (791-2). Whereas the knights of other cycles make a mockery of chivalry by reveling in the slaughter, the knights in Coventry lament their actions and the suffering they have caused, 'grettly reybukyng chewaldry' (818). They again emphasize the political ramifications of Herod's actions, fearing 'moche wengance' (822) and predicting that Herod will 'beyre the perell' (825). The pointlessness of this mass murder is brought home in the last lines of the pageant when the knights present Herod 'With waynis and waggyns' (827) full of slaughtered children, in the face of which the herald tells Herod that Christ has escaped to Egypt. Combined 
with the usual heart-wrenching lamentations of the women and the haunting melody of the familiar Coventry carol, the episode serves to contrast the joy of the one lucky, holy family with the despair of a bereaved population. The references to the political ramifications of Herod's actions help to situate this childlessness simultaneously in biblical and secular contexts, reinforcing the connection between the suffering women and the childless citizens of Coventry. As with the final episode of the Weaver's pageant, the emphasis on the slaughter in a secular context reinforces anxieties about the failure of the gerontocratic system as a result of a failing population. In addition, the Shearmen and Taylors' pageant suggests a more pointed critique: representations of authority are either corrupt (Herod) or powerless against corruption (the knights), posing a further threat to the audience's faith in gerontocratic authority.

Both pageants celebrate the gerontocratic model, while simultaneously raising the problem of that model's imminent failure as a result of a demographic crisis. Both also hint at the model's vulnerability to corruption when representatives of authority, the Doctors and Herod, put their own interests above the needs of the commoners. Neither pageant suggests a specific solution - indeed, they both express a nostalgia for gerontocracy as an ideal system of artisanal and civic authority - but they do point to the dearth of children as the most significant source of anxiety. Without newer members to take on the mantle of authority, Coventry's two guild system of governmental progression could not function effectively. Croo's 1535 revisions engage their audiences in an ongoing, local conversation over these issues, a conversation attested to by a subsequent Leet decision, never enacted, to amalgamate the city's two religious guilds. ${ }^{51}$ While the Corpus Christi Guild held its last banquet in $1534,{ }^{52}$ this was not, as Alakas suggests, the date of the proposed merger between the guilds. ${ }^{53}$ It was on 12 October 1535, seven months after Croo's revisions and just under three months since their premier Corpus Christi performance, that the Leet voted to annex the Corpus Christi Guild to the Trinity Guild by a vote of twenty to four. ${ }^{54}$ Despite the fact that this decision was not carried out, it was a logical response to financial and demographic difficulties. More importantly, the timing, just months after the revisions were performed, suggests that the pageants helped to emphasize the social significance of these problems to the citizens of Coventry as a whole. Coventry's two extant pageants record an awareness of the crises facing the city, revealing a shared anxiety about the failure of the administrative system and the implications of that failure for the stability of both craft and civic 
identities. Rather than attempting to provide closure or impose solutions, they speak to the community at large, identifying issues of general social concern and inviting participation in their solution.

\section{Notes}

I would like to thank Margaret Rogerson, Garrett Epp, Renée Ward, Elyssa Warkington, and my anonymous reviewers at Early Theatre for their keen and critical comments at various stages of the development of this material.

1 Theresa Coletti, 'Reading REED: History and the Records of Early English Drama', Literary Practice and Social Change in Britain, 1380-1530, Lee Patterson (ed) (California, 1990), 248-84.

2 Ibid, 279.

3 Ibid, 280.

4 Brandon Alakas, 'Seniority and Mastery: The Politics of Ageism in the Coventry Cycle', Early Theatre 9.1 (2006), 15-35.

5 Ibid, 21.

6 Coletti provides her analysis as one example in a larger discussion concerning the relationship of text and context. As such, her discussion of the Coventry pageants is not developed in any great depth and is largely superseded by Alakas's article. For this reason I will focus primarily on Alakas's argument in my own discussion.

7 Mervyn James, 'Ritual, Drama and Social Body in the Late Medieval English Town', Past and Present 98 (1983), 3-29, and Charles Phythian-Adams, 'Ceremony and the Citizen: The Communal Year at Coventry 1450-1550', Crisis and Order in English Towns 1500-1700: Essays in Urban History, Peter Clark and Paul Slack (eds) (Toronto, 1972), 57-85.

8 Phythian-Adams, 'Ceremony and the Citizen', 60-1, and The Desolation of a City: Coventry and the Urban Crisis of the Late Middle Ages (Cambridge, 1979), 114. While Phythian-Adams describes the civic structure in both texts, he first applies the term 'gerontocratic' in the later publication, The Desolation of a City.

9 Phythian-Adams, Desolation, 125-6.

10 This section provides a simplification of Phythian-Adams's own 'bald summary' of the gerontocratic system from Desolation, 125, also described in more detail in chapters 7-9 of Desolation. I use masculine references throughout because only men were eligible for these offices.

11 These statements summarize Phythian-Adams arguments in Part 2 of Desolation. 
12 Part 4, 'An Anatomy Deformed', of Desolation details the overall depopulation of the city as well as the specific problems of low replacement rates for servants and children.

13 R.W. Ingram (ed), REED: Coventry (Toronto, 1981), 149.

14 The 1392 record is a description of a tenement bordered on one side by the Drapers' pageant house. The presence of a pageant house may suggest the existence of a civic cycle, but the structure and content of this cycle does not appear in the records until much later.

15 Pamela M. King and Clifford Davidson (eds), The Coventry Corpus Christi Plays (Michigan, 2000), 5. All in-text citations to the text of the Coventry pageants will be by line number in reference to this edition. The original manuscript of the Shearman and Taylor's pageant is no longer extant, but the text has been preserved in Thomas Sharp's 1825 transcription in A Dissertation on the Pageants.

16 Ibid, 109, 148, 248, and 274. The old style Julian Calendar began the new year on March 25, as opposed to new style Gregorian Calendar's January 1 start date. Corpus Christi fell on May 27 in 1535, which suggests a rehearsal period of two and a half to three months (or eight to ten weeks).

17 Other cycles develop the comedy of the May-December marriage before the Nativity, but Coventry is the only extant English cycle to include this comic element after Christ is born.

18 Alakas, 'Seniority and Mastery', 22.

19 Ibid, 23.

20 Ibid, 24.

21 Ibid, 23-4 and 26. Alakas uses the Middle English Dictionary to support his definitions.

22 Ibid, 27, but see also 28, where he writes, 'theological knowledge is set within an artisanal register as Christ's disruption of the Doctor's authority is conflated with the recent disruption of the hierarchy centred on the aldermanic elite within the Trinity Guild'.

23 King and Davidson, The Coventry Corpus Christi Plays, 268-9.

24 Ibid, 267-8.

25 'Statute,' def. 1g, d. Middle English Dictionary. Dec. 2001. University of Michigan Press. 22 Jan. $2008<$ http://quod.lib.umich.edu/m/med/>.

26 'Article', def. 1, 2. Middle English Dictionary. Dec. 2001. University of Michigan Press. 22 Jan. $2008<$ http://quod.lib.umich.edu/m/med/>.

27 'Politike', def. 1a. Middle English Dictionary. Dec. 2001. University of Michigan Press. 22 Jan. $2008<$ http://quod.lib.umich.edu/m/med/>. 
28 'Allegeance' and 'alligeance.'. Middle English Dictionary. Dec. 2001. University of Michigan Press. 22 Jan. 2008 <http://quod.lib.umich.edu/m/med/>.

29 Mary Dormer Harris (ed), in The Coventry Leet Book or Mayor's Register (London, 1907-13), states that 'Information about the ... judicial procedure of the Coventry leet is scanty and hard to come by' (xx).

30 Alakas, 'Seniority and Mastery', 28 and 26.

31 Ibid, 30.

32 Ibid, 30.

33 Daniel T. Kline, 'Structure, Characterization, and the New Community in Four Plays of Jesus and the Doctors', Comparative Drama 26 (1992-3), 352. Kline argues that each city 'presents a distinctively structured version of the disputation' and that the outcome of the disputation in each play results in a unique 'articulation of principles which must be seen as the basis of new community' (344-5). With respect to Coventry, Kline concludes, 'The Coventry play especially illustrates neighborly love, for Jesus's divinity here, as in Towneley, is marked by human relations' (354). Given the city's long-term economic and demographic crisis, the emphasis on neighbourly love and community in Croo's version of the text may reflect the social qualities which were essential to Coventry's continued survival. Certainly the city was remarkable in conducting two censuses (in 1520 and 1523) and a survey of available grain resources (in 1520), as well as making early provision to distinguish the deserving poor from idlers, all of which indicates a strong sense of social responsibility.

34 King and Davidson, The Coventry Corpus Christi Plays, 273.

35 Alakas, 'Seniority and Mastery', 25.

36 The following analysis of the York analogue is based on Richard Beadle's edition in The York Plays (London, 1982), 174-81.

37 Phythian-Adams, Desolation, 83, also draws attention to Christ's age in the Weavers' pageant. Phythian-Adams discusses the age of adolescence further in Chapter 21, 'Children and the Future', Desolation, 229-30.

38 A third option would include going to school. Reading Jesus as a potential student echoes the biblical scene most closely, but does not attend to the artisanal and civic language of the Coventry pageant.

39 'Frend', def. 1b, 4. Middle English Dictionary. Dec. 2001. University of Michigan Press. 22 Jan. $2008<$ http://quod.lib.umich.edu/m/med/>.

40 I am grateful to Early Theatre's anonymous reviewer who made this suggestion, noting examples in Piers Plowman and The Canterbury Tales.

41 Phythian-Adams, Desolation, 83.

42 Ibid, 45. 
43 With respect to Joseph's authority, Alakas demonstrates that Mary functions as the actual head of the household in 'Seniority and Mastery', 20-3.

44 Phythian-Adams, Desolation, 232 and 235.

45 Ibid, 235-7.

46 Ibid, 227-8 for children, 208 for servants.

47 Ibid, 212.

48 'Communalte'. Middle English Dictionary. Dec. 2001. University of Michigan Press. 22 Jan. $2008<$ http://quod.lib.umich.edu/m/med/>.

49 Coletti, 'Reading REED', 279.

50 Claire Sponsler, Drama and Resistance: Bodies, Goods, and Theatricality in Late Medieval England (Minneapolis, 1997), 143.

51 The colophons to each pageant date the revision to 1534 , which is an old style date for 1535 . See note 16.

52 Phythian-Adams, Desolation, 269.

53 Alakas, 'Seniority and Mastery', 16.

54 Harris, The Coventry Leet Book, 722-3. I am grateful to M.J. Hinman, Assistant Archivist at the Coventry Archives, who clarified the later history of the Corpus Christi Guild, writing 'whatever the administrative intention, they continued to act separately, not only until theoretically suppressed under national legislation in 1545 , for the master and fraternity of Corpus Christi Guild let a piece of land in 1547 (our reference $\mathrm{BA} / \mathrm{B} / \mathrm{Q} / 13 / 3)$, but also until the corporation purchased both guilds' property in $1552(\mathrm{BA} / \mathrm{B} / \mathrm{P} / 102 / 3)^{\prime}$. 